\title{
Pengaruh Umur, Kehamilan Ganda dan Gravida pada Kejadian Preeklampsia di Rumah Sakit Umum Meuraxa Banda Aceh Tahun 2015
}

\author{
Effect of Age, Multiple Pregnancy and Gravida on Preeclampsia at Meuraxa \\ General Hospital in Banda Aceh in 2015
}

\author{
RaudhatunNuzul ZA*1, Rizky Swastika Renjani², Rini Astuti ${ }^{3}$ \\ 1,2Program Studi D-IV Kebidanan, Fakultas Ilmu Kesehatan, Universitas Ubudiyah Indonesia, Banda Aceh, Indonesia \\ ${ }^{3}$ Program Studi D-III Kebidanan, Fakultas Ilmu Kesehatan, Universitas Ubudiyah Indonesia, Banda Aceh, Indonesia \\ *Korespondensi Penulis: raudhatun@uui.ac.id
}

\begin{abstract}
Abstrak
Preeklampsia juga mungkin akan dibuat lebih rumit dengan hadirnya kejang-kejang yang disebut eklamsia dan mengakibatkan banyak kematian pada ibu terkait dengan hipertensi, data penderita preeklamsi dan eklamsi di ruang kebidanan rumah sakit umum Meuraxa tahun 2014 tercatat 491 yang melahirkan dengan kasus preeklamsi sebanyak 30 orang dan di tahun 2015 tercatat sebayak 560 orang yang melahirkan dengan kasus preeklamsi sebanyak 30 orang, dari data ini terdapat peningkatan di tahun 2015 sebanyak 69 orang melahirkan. Penelitian ini bersifat survey analitik dengan desain Case Control. Sampel penelitian ini sebanyak 40 orang yang terdiri dari 20 orang kelompok kasus dan 20 orang kelompok kontrol, kemudian di ujistatistik mengunakan chi-quare. Hasil yang didapatkan adanya pengaruh antara usia ibu dengan kejadian preeklamsi dan hasil nilai OR 21,000. Tidak ada pengaruh antara kehamilan ganda dengan kejadian preeklamsi dan hasil nilai OR 6,000. Ada pengaruh gravida dengan kejadian preeklamsi dan hasil nilai OR 0,076.
\end{abstract}

Kata Kunci: Kejadian Preeklamsi, Usia Ibu, Kehamilan Ganda, Gravida

\begin{abstract}
Preeclampsia may also be made more complicated by the presence of seizures called eclampsia and result in many maternal deaths associated with hypertension, data on patients with preeclampsia and eclampsia in the midwifery room at the Meuraxa General Hospital in 2014 recorded 491 who delivered as many preeclampsia cases as 30 people and in 2015 there were 560 people who gave birth with cases of preeclampsia as many as 30 people, from this data there was an increase in 2015 as many as 69 people gave birth. Method: This study is an analytical survey with Case-Control design. The sample of this study was 40 people consisting of 20 case groups and 20 control groups, then in statistical tests using chi-square. Research Results: the results obtained were an influence between the age of the mother and the incidence of preeclampsia and the results of OR 21,000. There was no effect between multiple pregnancies and the incidence of preeclampsia and the results of OR 6,000. There was an effect of gravida on the incidence of preeclampsia and the results were OR 0.076.
\end{abstract}

Keywords: Preeclampsia, Age of Mother, Double Pregnancy, Gravida 


\section{PENDAHULUAN}

Mengingat bahwa angka kematian ibu hamil akibat preeklamsi dan eklamsi setiap tahun meningkat. Jadi sebuah keperihatinan buat kita untuk mengkaji penyebab yang mempengaruhi eklamsi pada ibu hamil tersebut, pada tahun 2015di dunia sebesar 0-13\% di Singapura 0,13-6,6\% sedangkan di Indonesia 3,4-8,5\% (WHO, 2015).

AKI dan AKB di Indonesia masih tinggi dibandingkan dengan negara ASEAN lainnya. Menurut data Survei Demografi Kesehatan Indonesia (SDKI) 2007, AKI di Indonesia adalah 228 per 100.000 kelahiran hidup, AKB 34 per 1.000. Menurut data Survei Demografi Kesehatan Indonesia (SDKI), AKI di Indonesia masih tinggi jika dibandingkan dengan negara ASEAN lainnya, yaitu sebesar 228 per 100.000 kelahiran hidup, diketahui angka kematian ibu berkisar antara 2,5 - 14 per 100.000 kelahiran hidup dan diketahui bahwa 285 orang kematian ibu merupakan akibat langsung dari komplikasi kehamilan, persalinan, dan nifas hanya sekitar 15\% disebabkan oleh penyakit lain yang memburuk akibat kehamilan dan persalinan ibu. Untuk memenuhi target mengenai penurunan angka kematian ibu pada tahun 2015 maka diperlukan kerja keras sehingga perlu adanya antisipasi terhadap faktor risiko yang dapat menyebabkan kejadian preeklampsia pada ibu (Hanifa, 2013).

Angka Kematian Ibu (AKI) merupakan salah satu indikator untuk melihat derajat kesehatan perempuan. Angka kematian ibu juga merupakan salah satu target yang telah ditentukan dalam tujuan yaitu meningkatkan kesehatan ibu dimana target yang akan dicapai sampai tahun 2015 adalah mengurangi sampai 3/4 resiko jumlah kematian ibu. Dari hasil survei yang dilakukan AKI telah menunjukkan penurunan dari waktu ke waktu, namun demikian upaya untuk mewujudkan target tujuan pembangunan millenium masih membutuhkan komitmen dan usaha keras yang terus menerus (Depkes, RI, 2007).

Angka kematian ibu yang berhubungan dengan kehamilan dan persalinan masih sangat tinggi. Menurut World Healt Organization (WHO), sekitar 500.000 wanita hamil didunia menjadi korban proses reproduksi setiap tahun. Sekitar 4 juta bayi meninggal karena sebagian besar penanganan kehamilan dan persalinan yang kurang bermutu. WHO memperkirakan 15.000 dari sekitar 4,5 juta wanita melahirkan di Indonesia mengalami komplikasi yang menyebabkan kematian salah satunya pre-eklamsia (Hidayat, 2010).

Angka Kematian ibu adalah jumlah kematian perempuan pada saat hamil atau kematian dalam kurun waktu 42 hari sejak terminasi kehamilan tanpa memandang lamanya kehamilan atau tempat persalinan. Kematian yang dihitung dapat terjadi karena kehamilannya, 
persalinannya dan masa nifas bukan karena sebab-sebab lain seperti kecelakaan, terjatuh, dan lain-lain. Untuk mengetahui besaran masalah kesehatan ibu, indikator yang digunakan adalah Angka Kematian Ibu (AKI) (Profil Kesehatan Aceh, 2015).

Salah satu upaya untuk menurunkan Angka Kematian Perinatal (AKP) akibat preeklampsia adalah dengan menurunkan angka kejadian preeklampsia. Angka kejadian dapat diturunkan melalui upaya pencegahan, pengamatan dini, dan terapi. Upaya pencegahan kematian perinatal dapat diturunkan bila dapat diidentifikasi faktor-faktor yang mempunyai nilai prediksi. Saat ini beberapa faktor resiko telah berhasil diidentifikasi, sehingga diharapkan dapat mencegah timbulnya preeklampsia. Faktor resiko preeklampsia meliputi pekerjaan, pemeriksaan antenatal, pengetahuan, dan riwayat hipertensi (Cunningham, 2013).

Mortalitas dan mobiditas pada wanita hamil dan bersalin adalah masalah besar di negara berkembang. Di negara miskin, sekitar 25-50\% kematian usia subur disebabkan hal berkaitan dengan kehamilan. Penyebab langsung kematian ibu di Indonesia, seperti halnya di negara lain adalah perdarahan, infeksi, dan eklamsia (Saifuddin, 2006).

Preeklamsia /eklamsia merupakan salah satu penyebab utama morbiditas dan mortalitas di Indonesia. Sampai sekarang penyakit preeklamsia/eklamsia masih merupakan masalah kebidanan yang belum dapat terpecahkan secara tuntas. Preeklamsia merupakan penyakit yang angka kejadiannya di setiap negara berbeda-beda. Angka kejadian lebih banyak terjadi di negara berkembang dibanding pada negara maju. Hal ini disebabkan oleh karena di negara maju perawatan prenatalnya lebih baik. Kejadian preeklamsia dipengaruhi oleh paritas, ras, faktor genetik dan lingkungan (Gafur, 2012).

Penyebab preeklampsia belum diketahui sampai sekarang secara pasti, bukan hanya satu faktor melainkan beberapa faktor dan besarnya kemungkinan preeklampsia akan menimbulkan komplikasi yang dapat berakhir dengan kematian. Akan tetapi untuk mendeteksi preeklampsia sedini mungkin dengan melalui antenatal secara teratur mulai trimester I sampai dengan trimester III dalam upaya mencegah preeklampsia menjadi lebih berat (Manuaba, 2009).

Berdasarkan Profil Kesehatan Provinsi Aceh, di ketahui bahwa jumlah kematian ibu pada tahun 2015 di Aceh sebanyak 170 kasus. AKI tahun 2012 di Aceh sebesar 192/100.000 lahir hidup. berdasarkan penyebab kematian karena perdarahan masih cukup tinggi yaitu 46 orang (33,8\%), kemudian hipertensi dalam kehamilan ada 27 orang (19,8\%), dan infeksi 9 orang $(6,6 \%)$, abortus dan partus lama masing-masing 2 orang $(1,4 \%)$, penyebab lain 
termasuk karena penyakit sistemik dan riwayat persalinan sebelumnya ada 70 orang $(36,7 \%)$ dan selebihnya disebabkan karena penyebab lain (Profil Kesehatan Provinsi Aceh 2015).

Data penderita preeklamsi dan eklamsi di ruang kebidanan rumah sakit umum Meuraxa tahun 2014 tercatat 491 yang melahirkan dengan kasus preeklamsi sebanyak 30 orang dan di tahun 2015 tercatat sebayak 560 orang yang melahirkan dengan kasus preeklamsi sebanyak 30 orang, dari data ini terdapat peningkatan di tahun 2015 sebanyak 69 orang melahirkan (Profil RSUD Meuraxa Aceh Besar, 2015). Berdasarkan latar belakang diatas, peneliti merasa terdorong untuk meneliti tentang "Pengaruh Umur, kehamilan ganda, dan gravid pada kelainan preeklampsia di Rumah Sakit Umum MeuraxaTahun 2014”.

\section{METODE PENELITIAN}

Jenis penelitian ini adalah penelitian survei yang bersifat analitik dengan desain case control. Penelitian case control adalah jenis penelitian rancangan penelitian dengan cara membandingkan kelompok kasus (preeklamsi) dengan kelompok kontrol (tidak preeklamsi). Sampel dalam penelitian ini yaitu 1:1 (20:20) sehingga jumlah sampel sebanyak 40 orang. Data dalam penelitian ini dikumpulkan menggunakan data sekunder yang diperoleh dari buku register danRekam Medik di Rumah Sakit Umum Meuraxa Banda Aceh dari tahun 20142015.

\section{HASIL DAN PEMBAHASAN}

Tabel 1. Faktor Risiko Usia Ibu dengan Kejadian Preeklamsi pada Ibu Bersalin di Rumah Sakit Umum Meuraxa Banda Aceh Tahun 2014 - 2015

\begin{tabular}{|c|c|c|c|c|c|c|c|}
\hline \multirow{3}{*}{ No } & \multirow{3}{*}{ Usia ibu } & \multicolumn{4}{|c|}{ Kejadian Preeklamsi } & \multirow{3}{*}{ p-Value } & \multirow{3}{*}{ OR } \\
\hline & & \multicolumn{2}{|c|}{ Kasus } & \multicolumn{2}{|c|}{ Kontrol } & & \\
\hline & & $\mathrm{F}$ & $\%$ & $\mathrm{f}$ & $\%$ & & \\
\hline \multirow{3}{*}{$\begin{array}{l}1 . \\
2 .\end{array}$} & Risiko tinggi & 18 & 90 & 6 & 30 & \multirow{3}{*}{0,001} & \multirow{3}{*}{21,000} \\
\hline & $\begin{array}{l}\text { Tidak risiko } \\
\text { tinggi }\end{array}$ & 2 & 10 & 14 & 70 & & \\
\hline & Total & 20 & 100 & 20 & 100 & & \\
\hline
\end{tabular}

Dapat di lihat bahwa dari 20 kasus kejadian preeklamsi, ada 90\% ibu yang berisiko tinggi, sedangkan 20 responden pada kelompok kontrol yang tidak mengalami preeklamsi hanya $30 \%$ yang usia beresiko tinggi. 
Berdasarkan uji stastistik didapatkan $p$-value $=0,001,<\alpha=0,05$ sehingga dapat disimpulkan adanya pengaruh faktor risiko usia ibu terhadap kejadian preeklamsi pada ibu bersalin di rumah sakit umum Meuraxa Banda Aceh tahun 2014 - 2015. Sedangkan hasil OR 21,000 yaitu ibu yang memiliki usia resiko tinggi mempunyai peluang 21 kali lebih besar mengalami kejadian preeklamsia dibandingkan dengan ibu yang tidak berusia resiko tinggi.

Tabel 2. Faktor Risiko Kehamilan Ganda dengan Kejadian Preeklamsi pada Ibu Bersalin di Rumah Sakit Umum Meuraxa Banda Aceh Tahun 2014 - 2015

\begin{tabular}{|c|c|c|c|c|c|c|c|}
\hline \multirow{3}{*}{ No } & \multirow{3}{*}{$\begin{array}{c}\text { Kehamilan } \\
\text { Ganda }\end{array}$} & \multicolumn{4}{|c|}{ Kejadian preeklamsi } & \multirow{3}{*}{ p-Value } & \multirow{3}{*}{ OR } \\
\hline & & \multicolumn{2}{|c|}{ Kasus } & \multicolumn{2}{|c|}{ Kontrol } & & \\
\hline & & $f$ & $\%$ & f & $\%$ & & \\
\hline 1. & $\mathrm{Ya}$ & 8 & 40 & 2 & 10 & \multirow{3}{*}{0,068} & \multirow{3}{*}{6,000} \\
\hline 2. & Tidak & 12 & 60 & 18 & 90 & & \\
\hline & Total & 20 & 100 & 20 & 100 & & \\
\hline
\end{tabular}

Dapat di lihat bahwa dari 20 kasus kejadian preeklamsi, ada 40\% ibu yang tidak mengalami kehamilan ganda, sedangkan 20 responden pada kelompok kontrol yang tidak mengalami preeklamsi hanya $10 \%$ ibu tidak kehamilan ganda.

Berdasarkan uji stastistik didapatkan $p$-value $=0,068,<\alpha=0,05$ sehingga dapat disimpulkan tidak ada pengaruh faktor risiko kehamilan terhadap kejadian preeklamsi pada ibu bersalin di rumah sakit umum Meuraxa Banda Aceh tahun 2014 - 2015. Sedangkan hasil OR 6,000 yaitu ibu yang mengalami kehamilan ganda mempunyai peluang 6 kali lebih kecil mengalami kejadian preeklamsia dibandingkan dengan ibu yang tidak mengalami kehamilan ganda.

Tabel 3. Faktor Risiko Gravida dengan Kejadian Preeklamsi pada Ibu Bersalin di Rumah Sakit Umum Meuraxa Banda Aceh Tahun 2014-2015

\begin{tabular}{|c|c|c|c|c|c|c|c|}
\hline \multirow{3}{*}{ No } & \multirow{3}{*}{ Gravida } & \multicolumn{4}{|c|}{ Kejadian preeklamsi } & \multirow{3}{*}{ p-Value } & \multirow{3}{*}{$\mathbf{O R}$} \\
\hline & & \multicolumn{2}{|c|}{ Kasus } & \multicolumn{2}{|c|}{ Kontrol } & & \\
\hline & & $\mathrm{f}$ & $\%$ & $\mathrm{f}$ & $\%$ & & \\
\hline 1. & Primigravida & 6 & 30 & 17 & 85 & \multirow{3}{*}{0,001} & \multirow{3}{*}{0,076} \\
\hline 2. & Multigravida & 14 & 70 & 3 & 15 & & \\
\hline & Total & 20 & 100 & 20 & 100 & & \\
\hline
\end{tabular}

Berdasarkan Tabel 5.7dapat di lahat bahwa dari 20 kasus kejadian preeklamsi, ada $70 \%$ ibu yang multigravida, sedangkan 20 responden pada kelompok kontrol yang tidak mengalami preeklamsi hanya $15 \%$ yang multigravida. 
Berdasarkan uji stastistik didapatkan $p$-value $=0,001,<\alpha=0,05$ sehingga dapat disimpulkan ada pengaruh faktor risiko gravida terhadap kejadian preeklamsi pada ibu bersalin di rumah sakit umum Meuraxa Banda Aceh tahun 2014 - 2015. Sedangkan hasil OR 0,076 yaitu ibuyang tidak terjadi peluang besar akan terjadi kejadian preeklamsi.

\section{Pembahasan}

1. Pengaruh Umur Ibu dengan Kejadian Preeklamsi

Berdasarkan uji stastistik yang didapatkan $p$-value $=0,001,<\alpha=0,05$ sehingga dapat disimpulkan adanya pengaruh faktor risiko usia ibu terhadap kejadian preeklamsi pada ibu bersalin di rumah sakit umum Meuraxa Banda Aceh tahun 2014 - 2015. Sedangkan hasil OR 21,000 yaitu ibu yang memiliki usia resiko tinggi mempunyai peluang 21 kali lebih besar mengalami kejadian preeklamsia dibandingkan dengan ibu yang tidak berusia resiko tinggi.

Menurut penelitian yang dilakukan oleh Rahayu (2008) yang berjudul hubungan usia dan paritas dengan kejadian preeklamsia di rumah sakit Islam Sultan Agung Semarang. Hasil penelitian menunjukkan bahwa nilai $p$ - value $=0,002$ sehingga ada hubungan usia ibu dengan kejadian preeklamsia. Berdasarkan dari identitas responden yang diteliti sebagian besar ibu yang preeklamsia dialami oleh ibu yang usia pada saat kehamilannya diatas 35 tahun.

Penelitian yang dilakukan oleh Rohania (2011) yang berjudul faktor-faktor resiko terjadinya preeklamsia pada ibu hamil di rumah sakit Dr. H. Soewondo Kendal. Hasil penelitiannya didapatkan nilai $p$-value $=0,010$ sehingga ada hubungan usia ibu dengan kejadian preeklamsia. $80 \%$ kejadian preeklamsia dialami oleh ibu hamil yang usia beresiko tinggi. Sedangkan hasil $\mathrm{OR}=1,441$ yaitu ibu yang memiliki usia beresiko tinggi saat hamil tidak memiliki peluang 1.441 kali lebih kecil mengalami preeklamsi di bandingkan dengan ibu yang usia tidak beresiko.

Usia sangat memengaruhi kehamilan, usia yang baik untuk hamil berkisar antara 20-35 tahun. Pada usia tersebut alat reproduksi wanita telah berkembang dan berfungsi secara maksimal. Sebaliknya pada wanita dengan usia dibawah 20 tahun atau diatas 35 tahun kurang baik untuk hamil. Karena kehamilan pada usia ini memiliki ini memiliki resiko tinggi, seperti terjadinya keguguran atau kegagalan persalinan, bahkan bisa menyebabkan kematian. Wanita yang usianya lebih tua memiliki tingkat risiko komplikasi melahirkan yang lebih tinggi dibandingkan dengan yang lebih muda. Bagi wanita yang 
berusia diatas 35 tahun, selain fisik mulai melemah, juga kemungkinan munculnya berbagai risiko gangguan kesehatan, seperti darah tinggi, diabetes, dan berbagai penyakit lainnya termasuk preeklampsia (Ernawati, 2005).

Peneliti berasumsi bahwa usia ibu pada masa kehamilan merupakan salah satu faktor yang menentukan tingkat resiko kehamilan dan persalinan. Jika usia ibu bersalin usia > 35 tahun akan menyebabkan timbulnya permasalahan terutama kenaikan darah tinggi yang akhirnya akan menjadi preeklamsi. Hal ini disebabkan juga karena faktor usia yang sudah tua sehingga timbulnya berbagai macam penyakit seperti darah tinggi. Usia ibu hamil di bawah <20 tahun beresiko mengalami komplikasi preeklamsia karena organ reproduksi di usia tersebut belum siap untuk menanggung beban kehamilan dan kemungkinan komplikasi seperti terjadinya keracunan kehamilan atau preeklamsi dan plasenta previa yang dapat menyebabkan perdarahan pada saat persalinan. selain itu pada usia ini biasanya ibu belum siap secara psikis maupun fisik.

\section{Pengaruh Kehamilan Ganda dengan Kejadian Preeklamsi}

Berdasarkan uji stastistik didapatkan $p$-value $=0,068,<\alpha=0,05$ sehingga dapat disimpulkan tidak ada pengaruh faktor risiko kehamilan terhadap kejadian preeklamsi pada ibu bersalin di rumah sakit umum Meuraxa Banda Aceh tahun 2014 - 2015. Sedangkan hasil OR 6,000 yaitu ibu yang mengalami kehamilan ganda mempunyai peluang 6 kali lebih kecil mengalami kejadian preeklamsia dibandingkan dengan ibu yang tidak mengalami kehamilan ganda.

Penelitian yang dilakukan oleh Atikasari (2009) yang berjudul faktor-faktor yang berhubungan dengan preeklamsia pada ibu hamil di rumah sakit Islam Sultan Agung Semarang. Hasil penelitiannya didapatkan nilai $p$ - value $=0,086$ sehingga tidak ada hubungan kehamilan ganda dengan kejadian preeklamsia. Dari hasil penelitian ini masih rendahnya kehamilan ganda pada ibu hamil di rumah sakit Islam Sultan Agung.Dengan nilai $\mathrm{OR}=2.66$ yaitu ibu yang memiliki kehamilan ganda mempunyai peluang 2.66 kali yang mengalami kehamilan ganda di bandingkan yang tidak mengalami kehamilan ganda.

Kehamilan ganda atau kehamilan kembar adalah kehamilan dengan dua janin atau lebih. Kehamilan kembar adalah satu kehamilan dengan dua janin. Kehamilan kembar dapat memberikan resiko yang lebih tinggi terhadap bayi dan ibu. Pertumbuhan janin 
ganda lebih sering mengalami gangguan dibandingkan janin tunggal seperti kejadian preeklamsia akibat adanya beban penambahan sirkulasi darah kejanin (Purwanto, 2009).

Peneliti berasumsi bahwa faktor resiko kejadian preeklamsi adalah riwayat tekanan darah tinggi yang kronis sebelum kehamilan, riwayat mengalami preeklamsia sebelumnya, riwayat preeklamsia pada ibu atau saudara perempuan, kegemukan, dan mengandung lebih dari satu orang bayi. Oleh karena ibu kehamilan kembar merupakan penyebab terjadinya preeklamsi. Namun dalam penelitian ini tidak adanya faktor risiko kehamilan ganda dengan kejadian preeklamsi hal ini disebabkan karena masih rendahnya kehamilan ganda pada ibu bersalin.

3. Pengaruh Gravida dengan Kejadian Preeklamsi

Berdasarkan uji stastistik didapatkan $p$-value $=0,001,<\alpha=0,05$ sehingga dapat disimpulkan ada pengaruh faktor risiko gravida terhadap kejadian preeklamsi pada ibu bersalin di rumah sakit umum Meuraxa Banda Aceh tahun 2014 - 2015. Sedangkan hasil OR 0,076 yaitu ibu yang multigravida mempunyai peluang lebih besar mengalami kejadian preeklamsia dibandingkan dengan ibu yang primigravida.

Hasil penelitian yang dilakukan oleh Rahayu (2008) yang berjudu hubungan usia dan paritas dengan kejadian preeklamsia di rumah sakit Islam Sultan Agung Semarang.Hasil penelitian menunjukkan bahwa didapatkan nilai $p$-value $=0,000$ sehingga ada hubungan primigravida dengan kejadian preklamsi.

Penelitian yang dilakukan oleh Rohania (2011), berjudul faktor-faktor resiko terjadinya preeklamsia pada kehamilan di rumah sakit Dr. H. Soewondo Kendal. Hasil penelitiannya didapatkan nilai $p$ - value $=0,000$ sehingga ada hubungan paritas yaitu multigravida dengan kejadian preeklamsia. Gravida adalah wanita hamil. Gravida merupakan salah satu komponen dari status paritas yang sering dituliskan dengan notasi G-P-Ab, di mana G menyatakan jumlah kehamilan (gestasi), P menyatakan jumlah paritas, dan Ab menyatakan jumlah abortus (Varney, 2008).

Primigravida muda termasuk didalam kehamilan risiko tinggi (KRT) dimana jiwa dan kesehatan ibu dan atau bayi dapat terancam. Risiko kematian maternal pada primigravida muda jarang dijumpai dari pada primigravida tua. Dikarenakan pada primigravida muda dianggap kekuatannya masih baik. Sedangkan pada primigravida tua risiko kehamilan meningkat bagi sang ibu yang dapat terkena pre-eklampsia/ eklampsia 
(Manuaba, 2009). Menurut Varney (2008) multigravida adalah wanita yang sudah hamil, dua kali atau lebih. Paritas 2-3 merupakan paritas paling aman di tinjau dari sudut kematian maternal. paritas 1 dan paritas tinggi lebih dari 3 mempunyai angka kematian maternal lebih tinggi, lebih tinggi paritas, dan lebih tinggi kematian maternal. Resiko pada paritas juga akan lebih tinggi paritas, lebih tinggi kematian maternal. Resiko pada paritas 1 dapat ditangani dengan asuhan obstetrik lebih baik, sedangkan resiko pada paritas tinggi dapat di kurangi atau dicegah dengan keluarga berencana. Sebahagian kehamilan pada paritas tinggi adalah tidak direncanakan (Wiknjosastro, 2007).

Peneliti berasumsi bahwa ibu bersalin yang melahirkan pertama akan meningkatkan resiko terjadinya preeklamsia. Hal ini disebabkan karena pada awal kehamilan seorang wanita masih memiliki respon tubuh terhadap sirkulasi darah untuk mengahadapi kehamilan dan persalinan. Akibat adanya komplikasi tersebut maka timbulah tekanan darah tinggi yang menyebabkan terjadinya preeklamsi. Sesuai dengan hasil penelitian ini menunjukkan adanya hubungan primigravida dengan kejadian preeklamsia. Dalam penelitian ini juga masih banyak ibu bersalin primigravida dan mengalami kejadian preekalamsi.Hal ini disebabkan karena ibu yang melahirkan lebih dari dua kali akan meningkatkan resiko terjadinya gangguan pada saat kehamilan dan persalinan seperti terjadinya preeklamsi. Resiko multigravida dapat ditangani dengan asuhan obstetrik yang lebih baik, kurangi atau dicegah dengan keluarga berencana. Dalam penelitian ini ditemukan adanya faktor risiko gravida dengan kejadian preeklamsia.

\section{KESIMPULAN}

Ada pengaruh usia terhadap kejadian preeklamsi pada ibu bersalin di rumah sakit umum Meuraxa Banda Aceh ( $p$ value $=0,001$ ), ibu yang memiliki usia risiko tinggi mempunyai peluang 21 kali lebih besar mengalami kejadian preeklamsi di bandingkan dengan ibu yang tidak berusia risiko tinggi. Tidak ada pengaruh kehamilan ganda terhadap kejadian preeklamsi pada ibu bersalin di rumah sakit umum Meuraxa Banda Aceh ( $p$ value $=0,068$ ), ibu yang memiliki kehamilan ganda mempunyai peluang 6 kali lebih besar mengalami kejadian preeklamsi di bandingkan dengan ibu yang tidak mengalami kehamilan ganda. Ada pengaruh gravida terhadap kejadian preeklamsi pada ibu bersalin di rumah sakit umum Meuraxa Banda Aceh ( $p$ value $=0,001$ ), yaitu ibu yang tidak terjadi peluang besar akan terjadi kejadian preeklamsi 


\section{SARAN}

Diharapkan kepada responden yaitu ibu bersalin untuk lebih melakukan pencegahan pada saat hamil agar terhindari dari kejadian preeklamsi pada saat bersalin seperti menghindari makanan yang menyebabkan tekanan darah tinggi yaitu mengkonsumsi garam dan menghindari stres agar tidak adanya peningkatan tekanan darah yang akhirnya menyebabkan preeklamsi

\section{DAFTAR PUSTAKA}

Anisah.(2008). Faktor-faktor yang mempengaruhi Kejadian Preeklamsia Di rumah Sakit Umum Daerah Ajjatpannge Wattan Soppeng kabupaten Soppeng. Makassar: Jurusan Kebidanan Poltekkes.

Antho.(2012). Jurnal Penelitian Pengaruh Umur Dan Paritas Ibu Bersalin Terhadap Preek lampsia Berdasarkan Gejala Klinik. Di akses 21 Februari 2016

Arikunto.(2010). ProsedurPenelitian, Suatu Pendekatan Praktek. Jakarta: Rineka Cipta.

Atikasari.(2009).Faktor-faktor yang berhubungan dengan Preeklamsia pada Ibu Hamil di Rs Islam Sultan Agung Semarang.Semarang: Fakultas Ilmu Keperawatan Universitas Islam Sultan Agung.

Depkes RI. (2007). Angka Kematian Ibu Melahirkan. Jakarta: Depkes RI

Ernawati, Y.H. (2005). Faktor-faktor yang Berhubungan dengan Preeklamsi/ Eklamisia pada Ibu Hamil yang Hipertensi di Kamar Bersalin Rumah Sakit Umum Pusat Fatmawati Tahun 2002-2003.Jakarta: Jurnal Tesis.

Gafur, A dkk. (2012). Hubungan antara Primigravida dengan Preeklamsia. Jurnal KTI. Surakarta: Fakultas Kedokteran Universitas Muhammadiyah

Hanifa, W. (2013). Ilmu Kebidanan. Edisi ke-3. Jakarta: Yayasan Bina Pustaka Sarwono Prawirohardjo.

Hastono, Sutanto. (2006). Analisa Data Kesehatan. Jakarta: Universitas Indonesia

Manuaba, IBG. (2010). Ilmu Kebidanan, penyakit Kandungan dan KB untuk Pendidikan Bidan Edisi 2. Jakarta: EGC

Manuaba.(2009). Memahami Kesehatan Reproduksi Wanita. Edisi 2. Jakarta: EGC

Potter dan Perry. (2009). Funamental or Nursing: Konsep Proses dan Praktis. Jakarta: Salemba Medika

Prawirohardjo, S. (2009).Ilmu Kebidanan. Jakarta: PT. Bina Pustaka Sarwono Prawirohardjo

Profil Kesehatan Aceh. (2015). Profil Kesehatan Provinsi Aceh Tahun 2015. Aceh: Dinas Kesehatan Provinsi Aceh 
Rahayu, Sri. (2008). KTI Hubungan Usia dan Paritas dengan Preeklamsia di Rs Islam Sultan Agung Semarang. Semarang: Fakultas Ilmu Keperawatan Universitas Islam Sultan Agung

Rohania (2011).Faktor-faktor risiko terjadinya preeklamsia pada kehamilan di Rumah Sakit Dr. H. Soewondo Kendal. Universitas Diponegoro. Semarang

Rukiyah, LiaYulianti. (2010). Asuhan Kebidanan 4 Patologi. Jakarta : TIM.

Saifuddin, A.B. (2006). Buku Acuan Nasional Pelayanan Kesehatan Maternal Dan Neonatal. Jakarta: Yayasan Bina Pustaka.

Sarwono, P. (2010). Ilmu Kebidanan. Jakarta: Yayasan Bina Pustaka

Wibowo B., Rachimhadi T. (2006). Preeklampsia dan Eklampsia. Jakarta: Yayasan Bina Pustaka Sarwono Prawirohardjo.

Wiknjosastro, Hanifa. (2007). Ilmu Kebidanan.: Yayasan Bina Pustaka-Sarwono Prawiroharjo. Jakarta

World Health Organization. (2015). Kejadian Preaklamia. Di akses 20 Februari 2016 http://whqlibdoc.who.int/publications/2005/a85500 